Table 4

\begin{tabular}{|c|c|c|c|c|}
\hline \multicolumn{5}{|c|}{$\begin{array}{l}\text { How Urban, Mixed and Rural Counties } \\
\text { Voted on the Convention Question }\end{array}$} \\
\hline $\begin{array}{c}\text { Counties } \\
\text { Classified }^{\circ} \\
\end{array}$ & \multicolumn{4}{|c|}{$\begin{array}{l}\text { Number of Counties Whose Voters Favored } \\
\text { the Convention by the Following Percentages }\end{array}$} \\
\hline $\begin{array}{l}\text { Urban } \\
\text { Mixed } \\
\text { Rural }\end{array}$ & $\begin{array}{c}\text { Under } 31 \% \\
0 \\
13 \\
44 \\
(57)\end{array}$ & $\begin{array}{c}31-60 \% \\
7 \\
20 \\
6 \\
(33)\end{array}$ & $\begin{array}{c}\text { Over 60\% } \\
8 \\
1 \\
0 \\
(9)\end{array}$ & $\begin{array}{l}(15) \\
(34) \\
(50) \\
(99)\end{array}$ \\
\hline \multicolumn{5}{|c|}{$\begin{array}{l}\text { "Classification of counties into urban, mixed and rural groups is } \\
\text { based on the percentage of each county's population residing in } \\
\text { urban areas of } 2,500 \text { or more according to the } 1960 \text { census. Urban } \\
\text { counties have over } 60 \% \text {, mixed counties between } 31 \% \text { and } 60 \% \text { and } \\
\text { rural counties under } 31 \% \text { of their populations residing in urban areas. }\end{array}$} \\
\hline
\end{tabular}

\title{
MARKERS FOR REMEMBRANCE: THE MORMON TRAIL
}

\author{
by Lida L. Greene \\ Librarian, State Historical Library
}

Some months ago a lost marker was brought to the Iowa Historical Museum. It was wooden, the carving weathered and a little forlorn. It looked as though it had been hiding in a fence comer for a dozen hard Iowa winters. The legend read, "Mormon Trail".

In the years of the Civilian Conservation Corps in Iowa, 1933-1940, a whole platoon of these signs had marched across the old Trace in southern counties. Roy Chastain of Des Moines, then employee of the Iowa Conservation Commission, has good reason to remember both the Trail and the markers. He covered much of the ground between Montrose and Council Bluffs, helping to locate probable camp sites of the migrating Latter Day Saints and overseeing the planting of the signs that were to be a memorial of the great hegira (18461852).

Several years ago Roy Chastain brought to the Department of History the plat maps of Iowa counties he had used in the 1930s to mark the route of the Saints. Lee County to Pottawattamie, the trail was traced in red with dates and notations 
on Mormon Camps of Israel.

Roy Chastain grew reminiscent as we looked at the maps together. In Lee county, alongside the twist of the Mississippi river, was the penciled citation: "First crossing, Feb. 4, 1846". "I had a couple of helpers," Chastain recalled with a touch of humor. "Can't say their names, but there was a young kid who'd never had a job before and an older fellow-well, he'd been in show business before the depression. That was a pair." Near the Missouri river in Pottawattamie county was a red circle and a date, "June 14," alongside, "Young's (Brigham Young) camp." "The kid was awkward, a little scared maybe," Chastain went on remembering. "He'd never been away from home before. The actor - it was something to see him dancing around the marker tamping down the dirt."

When there was time to cover the southern Iowa maps more carefully, the Appanoose county chart called for special attention. Under the notes reporting "Chariton" (river) "camp" and "46" was the terse phrase, "Trail visible." No further description followed but any reader must pause to savor the fact that in almost ninety years the continuing sabotage of plow, wind and water had failed to level the road sculptured by thousands of burdened wheels.

Every county plat held its own small drama. In Decatur, Garden Grove was a reminder of the permanent way camp (1846-1852) established by Brigham Young and the leaders of the Saints for the sick and the poor and the emigrants who were to follow. Journals left by members of the first party reveal a portrait of beehive industry. "At the sound of the horn" one of them wrote, the work began on the morning of April 27, 1846. A hundred men hewed rails and laid crisscross fences. A half hundred felled trees and shaped logs for buildings. Others dug wells, mended plowshares, struggled with the reluctant sod and planted crops. Within two weeks the job was well under way and the wagons rolled out, west by northwest, toward the Missouri.

In Union County, the map details a serpentine track leading to Mt. Pisgah, a hill with a clear cold spring, that was discovered and christened by Elder Parley Pratt of the advance 
scouts in May, 1846. This site became the next Mormon way station. History relates that craftsmen explored the neighboring branch of the Grand river and set up a mill. Builders again raised log structures for housing and storage: Farmers plowed and planted gardens. When the pioneering company moved ahead, a colony remained at Pisgah to serve the needs of the church in exodus:

Lee, Van Buren, Davis, Appanoose. . .Following the 1930 maps in sequence, a counting was made of the dots and circles showing the placement of wooden markers at Mormon camps and river crossings on the Trace. Lee county had seven posted sites; Pottawattamie, 24. The total for the whole route from Montrose to Council Point on the Missouri was an impressive one hundred. For Roy Chastain and his crew this meant one hundred post holes for one hundred marker standards. The actor-did he dance to dedicate every one of them?

There are other memorials along the Mormon Trace in southern Iowa. The Daughters of the American Revolution, with the encouragement and assistance of Edgar R. Harlan, curator of the Iowa Department of History, placed boulders and plaques at strategic points along the route to Council Bluffs. Harlan, in 1911, had retraced the main trail of the Latter Day Saints from reports and field maps of early surveyors who noted the road as they did rivers and other physical landmarks. His study, The Location and Name of the Mormon Trail, separately published in 1913, is still available for the serious student of migration through Iowa. Roy Chastain carried a copy of the Harlan notes along with the plat book on which he traced the line of markers in the 1930s.

The D.A.R. memorials were placed at Brattain's Grove, Wapello county, 1917; Chariton, Lucas county, 1917; Council Bluffs, Pottawattamie county, 1917; and Orient, Adair county, 1917. The latest, 1923, was established at the site of old Indiantown in western Cass county where the trail from Ft. Des Moines met the Trace from the southern route.

Pisgah of the Saints has its own monuments. The mill on the Grand river is long gone but the mill stones remain in the collection at the Iowa Historical Building. An obelisk on a two acre plot of ground stands at the site. Erected in 1888 
it lists the names of those for whom Mt. Pisgah was the last stop on the road to sanctuary. Annually, the Latter Day Saints of central Iowa make a pilgrimage to the spot. Men with mowers and sickles discipline the grass. Children race in the sun. Families sit down together to food and laughter. Sometime during the day there are moments of quiet remembering. A leader's voice, perhaps, reads aloud the roll from the stone of witness: William Huntington, first presiding elder of Pisgah; Lenora Charlotte Snow; Hyman Spencer; Mrs. Baldwin and baby; Jesse Hitchcock a stranger not of the church. . .

All history of significance to a people"s heritage will at sometime need renewal by remembering and retracing. In recent years Iowa has turned its attention to the Hiawatha Pioneer route we share with Minnesota and Wisconsin. Sherry Fisher of the Lewis and Clark Trail Commission and the news media have kept us aware of adventuring years when a young America was reaching for the Pacific. Perhaps it is time for a fresh retelling of the Mormon Trace story.

The Adair County Historical Society is already at work gleaning information on its sector of the Mormon road. Other. trail counties who would like to retrace the way might look for the Civilian Conservation Corps markers of the 1930s. If the wooden signs have disappeared, the Department of History can provide the Harlan routing by township and section.

Some of you will go with your children to Pisgah's hilltop or stop to read the plaque on the boulder at old Indiantown. You will tell your young people about the long procession of Mormons who made a homeland in the desert. You will remember the land-hungry eager for Oregon, the argonauts lured by the Sacramento's gold, the free-staters of the $1850 \mathrm{~s}$ heading for Kansas and the first sanguine encounter leading to the War of Brothers. If you belong to the Whittier-reading generation you may even peruse the quatrain imbedded in the legend of the plaque:

"We crossed the prairie as of old The pilgrims crossed the sea

To make the west, as they the east The homestead of the free." 
Copyright of Annals of Iowa is the property of State of Iowa, by \& through the State Historical Society of Iowa and its content may not be copied or emailed to multiple sites or posted to a listserv without the copyright holder's express written permission. However, users may print, download, or email articles for individual use. 